\title{
Education Supervision in Increasing Competence Teachers in Curriculum 2013 (Study of Education Management Analysis)
}

\author{
Bahdin Nur Tanjung \\ Universitas Muhammadiyah Sumatera Utara, Indonesia \\ Email: 1bahdinnur@umsu.ac.id
}

\begin{abstract}
Administrators must be transferred to ensure quality learning. That is, that the success of the implementation of supervision is measured by increasing student learning achievement. Tenriningsih (2009) believes that there is a positive and significant direct relationship between master's performance and positive and significant achievement between student achievements through teaching administrators". This means that the higher the master's performance. The higher the student's learning achievement is then to produce the necessary teacher supervision effective for teaching. Supervision of education develops along with the development of management science. At the beginning of its development, supervision was carried out using an inspection approach. Supervisor comes to school and observes the teaching of the teacher. The focus of the supervisor's attention is to find teachers' mistakes based on work standards formulated in such a way by the education authority. The teacher carries out the task in accordance with standard operational procedures. Supervisors with teachers are two parties as subordinate superiors. Supervisors have a higher level of truth. The research method by the author uses the systematic method Literature Review (SLR), by gathering several sources of information from journals, books and other articles. To improve the source of reading that will be produced by the reader later. Then after the sources are collected, the new author can conclude what results have been obtained from this reading source.
\end{abstract}

Keywords: supervisors; curriculum; management

\section{Introduction}

The development of science, technology, and the socio-economic community can further increase variations in capacity development. In general it is known, supervision is carried out by administrators by conducting class visits. The administrator prepares teaching preparation and comments on the teaching preparation made by the master. Next, make a teaching and note everything about the implementation of learning conducted by the master. Observations are discussed with the master; The administrator gives comments to the master about things that need to be fixed. Related to supervision that is not always done in full. Supervision is often done only when completing a learning plan or approval of the implementation of learning in class.

Administrators must be transferred to ensure quality learning. That is, that the success of the implementation of supervision is measured by increasing student learning achievement. Tenriningsih (2009) believes that there is a positive and significant direct relationship between master's performance and positive and significant achievement between student achievements through teaching administrators". This means that the higher the master's performance. The higher the student's learning achievement is then to produce the necessary teacher supervision effective for teaching. 
Supervision of education develops along with the development of management science. At the beginning of its development, supervision was carried out using an inspection approach. Supervaisor comes to school and observes the teaching of the teacher. The focus of the supervisor's attention is to find teachers' mistakes based on work standards formulated in such a way by the education authority. The teacher carries out the task in accordance with standard operational procedures. Supervisors with teachers are two parties as subordinate superiors. Supervisors have a higher level of truth.

Teacher's expertise in carrying out educational tasks is obtained after taking certain teacher education that is not possessed by other professions. There are several roles teachers can play as educators, including: (a) As a professional worker with the function of teaching, guiding and training. (b) Humanitarian workers with the function can realize all their human capabilities. (c) As a benefit officer with the function of teaching and educating the public to be good citizens (Saragih and Mardianto, 2019).

Education is part of the intellectual life of the nation as mandated in the 1945 Constitution, likewise in the Law of the Republic of Indonesia No. 20 of 2003 concerning the National Education System which states that the goal of national education is to educate the life of the nation, to develop the potential of students so that they can become people who have faith and are devoted to God Almighty, noble, capable, creative, independent and become citizens of a democratic and responsible country. To that end, the government has sought to develop the education sector in a planned, directed, and gradual manner and integrated with the overall development of the nation's life, both economic, social, cultural, scientific and technological. (Rasien, 2020)

The education unit level is a curriculum that has been implemented in Indonesia since 2006, this curriculum is an improvement from the previous curriculum of the Ministry of Education and Culture (2012: 2) which is considered to have problems in its implementation and is not responsive to social changes that occur at the local, national, global. The SBC evaluation standard does not affect competency-based assessment. This is contrary to the explanation of Law No. 20 of 2003 that graduate competencies are the qualifications of graduates' abilities including attitudes, knowledge, and skills in accordance with agreed national standards.

Turned into the 2013 curriculum also carried out on reducing subjects at the elementary level, junior high school, as well as adding class hours in the 2013 curriculum, therefore supervision needs to be increased for teachers in implementing the 2013 curriculum and supervision by supervisors. So that gradual change can be obtained by teachers, the more often the supervision the better the condition of education in Indonesia. Especially teachers in regions that have a minimum level of facilities in conducting learning activities.

\section{Research Methods}

The research method by the author uses the systematic method Literature Review (SLR), by gathering several sources of information from journals, books and other articles. To improve the source of reading that will be produced by the reader later. Then after the sources are collected, the new author can conclude what results have been obtained from this reading source. 


\section{Discussion}

\subsection{Educational Supervision}

Supervision of education develops as management science develops. At the beginning of its development, supervision was carried out using an inspection approach. The supervisor comes to the school and says that the teacher teaches the supervisor to search based on work standards. The focus of attention on teacher errors is formulated in such a way by the education authority. The teacher carries out the task in accordance with standard operational procedures. Supervisors with teachers are the two parties as superiors and subordinates. Supervisors have a higher level of truth than teachers. There are several more popular surveillance approaches known as clinical, developmental, and differential supervision. Each of these approaches has strengths and weaknesses. Such as (a) clinical supervision was first developed based on the idea of diagnosis and treatment in the medical field by Morris Cogan and colleagues in 1950 in a laboratory school at Harvard University. This approach is influenced by behaviorist theory. Likewise, Acheson and Gell (2003: 4) argue that the characteristics and distinctive styles of teachers are closely related.

The word "clinical" refers to the face-to-face interaction between the teacher and the supervisor which emphasizes solving reflective problems, directly targeting each class, and focusing on the teacher as an agent of change. Clinical capacity develops the ability of teachers to analyze responsible performance so that they can help others open and direct themselves. Clinical supervision is carried out in a process that allows supervisors to interact and meet face to face. Sergiovanni and Starratt (2002: 22) state clinical supervision as face-to-face contact with learning tools to reap professional improvement. A key element of the clinical supervision process is collecting data on the actual class. Goldhammer (1980: 19) holding clinical supervision is a learning phase that gets actual teaching event data from direct observation. (B) Development Supervision. The development of supervision was pioneered by Carl D Glickman who had effectiveness in carrying out the development process in a sustainable manner and had development theories such as Erickson and Piaget. Who often use models and often treat differently at various stages of development and growth. This assumption is based on a model that teachers' experiences vary greatly in their careers and abilities. There for the supervisor determines the teacher's need for individual commitment and expertise.

\subsection{Educational Supervision Objectives}

The purpose of supervision is to know the situation and see the level of development of school activities in an effort to achieve goals or in other words the purpose of supervision is to develop better learning and teaching situations, so that supervision aims to conduct evaluations to measure school progress. The purpose of educational supervision in the Education Administration book written by Daryanto (172: 2011) to achieve the goal of education supervision is to follow up supervision, it is necessary to provide guidance or advice from supervisors to teachers and employees and school officials to improve the quality of results in the learning process and try removes obstacles that have been evaluated previously. So that the main purpose of education supervision is to find out the situation and condition of the learning process at school so mistakes can be detected so that improvements can be made through the evaluation process and direction by supervisors to teachers and school staff, so it turns out to be wasted in a better teaching and learning process and quality. Fine again.

Unlike the era before independence, supervision only aims to find faults and give gifts or punishment to public schools that are examined and seen without providing counseling or input as well as suggestions to correct mistakes and improve the quality of education. This is 
different from the post-independence era where supervision was conducted to build and improve the quality of schools so that they could be better. This is clearly stated in the Education and Teaching Law No. 12 of 1954 Chapter XVI which reads: "Supervision of education and teaching means giving leadership to teachers to achieve perfection in their work."

Therefore, a teacher must always be able to keep abreast of the times and information so that we will not lose and lose money in science, especially science, so that development, improvement for improvement will continue to be improved to achieve better quality. That is why this development, improvement and improvement is contained in the sense of supervision. Society will advance if education is advanced, basic education if the teacher is advanced and progressive, there are those who move it, there are those who lead it to improve and develop their profession. Guidance like this from supervision.

Based on the things described above, supervision means supervision carried out by people who are experts or professionals in their fields so that they can provide improvements and enhancements and guidance so that learning can be done well and of high quality. So in the opinion of some of the experts above regarding supervision it can be concluded that supervi is everything that is done together that requires planning and supervision of the steps that must be taken and used for the growth and improvement and effectiveness of teaching and learning conditions for both students and teachers. school teachers. Sambel (Mobley: 2005) suggests that supervisors need to develop effective supervision that is characterized by delegation, balance, communication, and technical skills development related to the supervisor's role as a quality guarantor, namely the role of research, evaluation, improvement, and development.

\subsection{Teacher Competency}

The teacher is one of the main factors for the creation of a nation's future generation for the creation of a quality nation's future generation, not only in terms of intelligence but also in terms of behaving in society. The teacher has a very important role in determining the quantity and quality of teaching done in class. Teachers according to Law No. 14 of 2005 concerning Teachers and Lecturers is "professional educators with the main task of educating, teaching, guiding, directing, training, evaluating, and evaluating students in early childhood education, formal education pathways, basic education and medium education". Teachers are professionals who have functions, roles and positions that are very important in achieving the vision of education in 2025, namely creating smart and competitive Indonesians. The role of a teacher is not as teaching but as a facilitator, motivator and evaluator, both in terms of students' knowledge and attitudes. So the duties and responsibilities of the teacher are not only transferring knowledge to students but are also required to form students who are marked by students who have faith, have good morals, are able to be independent, beneficial to religion and nation.

Competence comes from English, namely competence which means skills and abilities. Competence according to Law No. 13 of 2003 concerning Manpower "is the ability of each individual to work which includes aspects of knowledge, skills and work attitudes in accordance with specified standards". According to Santosa's Big Indonesian Dictionary (2015: 405) the idea "competence is the power to determine or decide something". In teaching systems, competencies are used to describe professional abilities, namely the ability to demonstrate knowledge and conceptualization at a higher level. This competency can be obtained through education, training and other experience in accordance with the level of competence. Sudjana (2004: 17) states that "Teacher competence is a basic ability that must be 
possessed by teachers". According to Sudrajat (2007: 11) "Teacher competence is a description of what a teacher must be able to do in carrying out his work, both in the form of activities in behavior and expected results". Based on the description above, it can be concluded that teacher competence is the ability in the form of knowledge, skills and attitudes that are lived and mastered by the teacher in carrying out their professional duties. Competent teachers are teachers who carry out the functions and objectives of the school and have the competencies needed by teachers to be able to carry out their duties as best they can. In other words, competent teachers are professional teachers. Teacher competition as a useful tool to provide the best service so that students feel satisfied in the learning process. Teacher competencies are divided into four types, namely many different classifications between experts but have the same core.

Pedagogical competence is the ability to manage student learning which includes student understanding, designing and implementing learning, evaluating learning outcomes and developing students to actualize their various potentials. Santoso (2013: 90) argues that "pedagogical competence is the ability to manage students which includes the scope of:(1) Ability to understand student characteristics; (2) Ability to do learning; (3) Ability to evaluate learning outcomes; and (4) the ability to develop students' potential ".

Personality competence is the ability of teachers who have a steady, stable, mature, wise and authoritative personality, become an example for students and have good morals. The scope of personality competencies includes: (1) The ability to display a stable, stable, mature, wise and wise and authoritative personality; (2) The ability to present oneself as a person who has a noble character and can be used as an example for students; and (3) The ability to evaluate one's own performance and develop yourself in a sustainable manner. "

Professional competence is the ability to master broad and deep learning material. The scope of professional competence is: (1) The ability to master the material, structure, concepts and scientific thought patterns that support subjects; (2) The ability to develop learning material that is taught creatively; (3) The ability to develop professionalism on an ongoing basis by taking reflective action; and (4) The ability to use information and communication technology to develop themselves ". Based on the description above, it can be concluded that professional competence is the ability of teachers to plan and implement the learning process. The teacher has the task to direct student learning activities to achieve learning goals. Teachers must always updating, and mastering the subject matter presented.Preparation about the material sought by finding information through various sources such as reading the latest books, accessing from the internet, always keeping abreast of the latest developments and progress on the material presented.

\subsection{Curriculum 2013}

The development of the 2006 curriculum into the 2013 curriculum is expected to change the mindset of teachers, especially related to assessment standards. Sutrisno (2005: 147) says that "there are three interrelated factors in education, namely goals, learning process, and evaluation". The objectives will be a reference for the learning and evaluation process. The learning process determines whether educational goals are achieved or not. Only with the correct evaluation of educational goals can the results be found, so they are very useful as feedback for educational programs.

Evaluation as part of the education process must be comprehensive, taking into account aspects of learning. In the sense that the assessment conducted so far is still focused on knowledge. A gradual evaluation of the learning outcomes is needed, which is based on 
aspects of knowledge, attitudes, and skills. Therefore, the orientation of education is changed in the 2013 curriculum which refers to three aspects. In the 2013 curriculum, the evaluation used was known as authentic assessment. For this reason, a study is needed to determine whether the authentic assessment process affects students' motivation and learning outcomes.

The 2013 curriculum was developed by continuing to develop a curriculum that was pioneered in 2004 to include integrated attitude, knowledge and skills competencies. Elements of changes in the 2013 curriculum include changes in graduate competency standards (SKL), process standards, content standards, and assessment standards. SKL is divided into areas of attitude, skills and knowledge. Permendikbud (2013) explains the procedure for preparing the 2013 KD curriculum by evaluating KD SK KTSP then maintaining the old KD SK in accordance with the new SKL and revising the old KD SK adjusted to the new SKL, and preparing a new KD SK. Subject guide is a complete profile of subjects that contains background, characteristics of subjects, core competencies and basic competencies of subjects, learning designs, learning models, assessments, media and learning resources, and the teacher's role as a school culture developer guides the subjects for each subjects are developed by the government and / or regional government in accordance with their authority. Subjects guidelines are used by educators to: fully understand subjects in accordance with the characteristics of the 2013 Curriculum; and references in the preparation and implementation of learning implementation plans.

The 2013 curriculum orientation is an improvement and balance between attitude competencies, skills and knowledge. This is in line with Law No. 20 of 2003 which explains that graduate competencies are the qualifications of graduates' abilities that include attitudes, skills and knowledge in accordance with national standards. For this reason, in its development in the 2013/2014 school year, the 2013 curriculum was implemented, where there were changes, including in the replacement of assessment standards, namely by using authentic assessments.

Authentic assessment focuses on three aspects of assessment, namely affective, cognitive, and psychomotor. Authentic assessment tries to combine teacher teaching activities, student learning, motivation, and student involvement and student skills. This activity can be assessed directly and continuously. This means that the assessment is not based on ranking because in this assessment see the input of students with different abilities that are different from each other. Authentic assessment can be done by the teacher himself, the teacher in the team or the teacher working with students. Assessments are carried out to monitor the process, learning ability, and continuous improvement of student learning outcomes.

It is hoped that there will be a change in the role of students in accordance with the 2013 curriculum. The role of students in learning develops into active participants, making decisions about what and how they learn, building new knowledge and skills based on knowledge and skills mastered, understanding expectations and encouraged to use steps selfassessment steps, monitor independent learning to develop learning strategies, collaborate with other students and do authentic learning.

The role of the teacher according to the 2013 curriculum is to conduct active studentcentered learning. Things that can be done include recognizing and accommodating different learning modalities, listening and respecting student characteristics, encouraging and facilitating students in making decisions, overcoming problems by asking open questions to help students reach conclusions or problem solving. If all components work well, it will affect student outcomes and motivation. Harris (2013) emphasizes that "students' position as a 
center of learning makes learning experiences, interests, and learning styles the focus of building an active and student-centered learning environment". Student-centered learning will make students more motivated in learning

\section{Conclusion}

Supervision is one of the best ways to measure the abilities / competencies of educators, both teaching lecturers and other education personnel in order to improve the quality of education in Indonesia, especially in improving the conventional curriculum-based learning process that turns into a centralized direction. The 2013 curriculum is the best alternative for students to change their character and behavior so they have the ability to hone their instincts and powers of reasoning and be active in classroom learning.

\section{References}

Acheson, Sons, Inc. K., \& Gall, M. D. (2004). Clinical supervision and teacher development: preservice and inservice applications (5th ed.). New York: John Wiley \& Son, Inc.

Daryanto. (2011). Administrasi pendidikan. Jakarta: Rineka cipta.

Elfrianto, I.Dahnial, Al-Khowarizmi, Tanjung, Bahdin Nur. 2020 The Antecedents of School Medical Room Management System in Preventing the Presence of COVID-19 in Indonesia to Improve the Health Quality of Students: A Systematic Review.

Goldhammer, R, Anderson, R. H. \& Krajewski, R. J. (1980). Clinical supervision-special methods for the supervision of teachers. US A: Holt, Rinehart and Winston.

I.Dahnial. (2017). Analisis Kompetensi Guru PKn Dalam Menerapkan Kurikulum 2013. Jurnal Tematik, 4 Desember 2017.

Kementerian Pendidikan dan Kebudayaan (Kemendikbud). (2012). Bahan Uji Publik Kurikulum 2013. Jakarta: Kemendikbud.

Rasien. (2020). The Effect of Blended Learning Strategy and Creative Thinking of Students on the Results of Learning Information and Communication Technology by Controlling Prior Knowledge. Budapest International Research and Critics in Linguistics and Education (BirLE) Journal. P. 879-893.

Saragih, K., and Mardianto. (2019). Relationship between Teacher Professional Performance and Discipline of Workers withTeacher Professionalism in Madrasah Tsanawiyah in Pematangsiantar City. Britain International of Linguistics, Arts and Education (BIoLAE) Journal; 1(2): 77-84.

Sergiovanni, T. J., \& Starratt, R. J. (2002). Supervision: a redefinition (ih ed.). Boston: McGraw - Hill.

Santoso, J. T. (2013). Strategi Pembelajaran Akuntansi. Semarang: YSBJ KANTHIL.

Sudjana, N. (2004). Dasar-dasar Proses Belajar Mengajar. Bandung: Sinar Baru Algensido Offset.

Tenriningsih, Andi. (2013). Supervisi Pengajaran Tingkatkan Kualitas Pembelajaran. (online:http://www.kopertis9.or.id/beri ta/view/650/4, tanggal 1 Juni 2013).

Undang-Undang Nomor 13 Tahun 2003 Tentang Ketenagakerjaan.

Undang-Undang Nomor 20 Tahun 2003 Tentang Sistem Pendidikan Nasional. 